\title{
Evaluate the Efficiency of Gamma Irradiation and Chitosan on Shelf-Life of Strawberries Fruits
}

\author{
Ehab A. Salem ${ }^{1}$, Abeer A. Ali ${ }^{2}$ \\ ${ }^{1}$ Food irradiation department, National center for Radiation Research and Technology, Atomic Energy Authority, Egypt. \\ ${ }^{2}$ Mycological Res. and Plant Dis. Survey Dept., Plant Pathology Research Institute, Agricultural Research Center, Giza, \\ Egypt.
}

\begin{abstract}
Chitosan play an important role as an antifungal against Botrytis cinerea and the effect was a concentration dependent. The obtained results of in vitro experiment demonstrated that chitosan (4\%) decreased radial growth of $B$. cinerea to $80 \%$. In vivo the severity of infection reduced from 59.8, 89.4 and 100.0 to 9.7, 33.8 and 40.1 in first, second and third week's storage periods at $13{ }^{\circ} \mathrm{C}$, respectively. Also, chitosan coating (4\%) significantly caused an increase in fruit firmness whereas TSS was decreased with an increase by increasing in storage time. However, Vitamin $C$ gave fluctuated results by increasing storage time. Gamma irradiation at 2.5 $K G y$ reduced severity (\%) of infected fruits from 55.5, 100 and 100 to 31.7, 45.9 and 49.9 and in healthy fruits severity (\%) reduced from 48.9, 100 and 100 to 23.3, 25.1 and 29.1 in different storage periods 1, 2 and 3 weeks, respectively. Similarly, chitosan as well as gamma irradiation combination induced a significant increase of peroxidase enzyme (POD) activity. Induced changes in surface morphology and damage of cell structure caused by using chitosan shown by scanning electron microscopy. Also, gamma irradiation causes changes in hyphea structure and in surface morphology but combination of gamma irradiation with chitosan was more effective in altering fungus morphology and cell structure damage and no spore forming. This providing the efficiency of combination on reducing disease severity (\%) of strawberry.
\end{abstract}

Keywords- gamma irradiation, chitosan coating, strawberry fruits.

\section{INTRODUCTION}

Strawberries (Fragaria $x$ ananassa Duch.) is a highly perishable fruit in a postharvest stage due to fungal infections. The shelf-life of fresh fruits at low temperature $\left(0-4^{\circ} \mathrm{C}\right)$ was around 5 days.

Braun and Sutton (1987) showed the postharvest decay represent major losses in horticultural industry. Losses during storage and shipment of fruits by Botrytis cinerea and Rhizopus stolonifer caused gray mold and soft rot, diseases, respectively.

Application of fungicides is an effective method to control postharvest disease. However, chemical control program faces imminent problem first there are reports on increasing number of fungicide-resistant strains of postharvest fungi and second is the health risk concerns. Thus, there is a growing need to one tactic that is being actively pursued involves: the use of bio-active substances (Tarek, 2004).

Chitosan, a high molecular weight cationic polysaccharide has been shown to be fungicidal against several fungi (E-Ghaouth et al., 1990).

Vargas et al., (2006) found that, chitosan treatment of strawberry fruits delayed the occurrence of fungal infections compared with the uncoated fruits which started to decay from the beginning of storage.

Gianfranco Romanazzi, et al. (2013) found that the commercial chitosan formulation was effective in the control of gray mold and Rhizopus rot of strawberries when immersed in this solution and preserved for 4 days at $20 \pm 1 C^{\circ}$.Shiekh, et al. (2013) confirmed that the chitos an is edible active coatings, maintain the quality and expand shelf-life of fresh fruits and prevent microbial damage.

Milena Petriccione et al. (2015); reported that chitosan coating significantly reduced water loss and delayed the qualitative changes in color, titratable acidity and ascorbic acid content of strawberry also chitosan coating enhanced the activity of some antioxidant enzymes, preventing flesh browning and reducing membrane damage.

Gamma irradiation was evaluated for its in vitro and in vivo antifungal activity against Botrytis cinerea on cut rose varieties. The irradiating dose required to reduce the population by $90 \%$ was $0.99 \mathrm{kGy}$. Gamma irradiation showed complete inhibition of spore germination and mycelia growth of B. cinerea especially $4.0 \mathrm{kGy}$ in vitro (Chu et al., 2015). 
Combinatory treatments have also widely been investigated to give synergistic effects. Gamma irradiation in combination with other treatments (e.g., heat, washing, modified atmosphere storage and edible coating process) give an effective result in extending shelf-life of the fruits. (Hussain et al., 2013).

The aim of the present work was to increase the shelf-life of strawberries fruits using gamma irradiation and chitosan

\section{MATERIALS AND METHODS}

Strawberry fruits collected from different fields of El-Sharkia governorate were classified into two groups healthy and decayed fruits. Decayed fruits were examined after 3 day of storage at $13^{\circ} \mathrm{C}$. The developing fungal colonies were picked up and examined.

Isolation, purification and identification of causal organisms:

Rotted fruits of strawberry were rinsed several times with sterilized water, surface disinfected by $70 \%$ ethanol, dried and cut into small pieces. These parts were cultivated in sterilized Petri dishes contained potato dextrose agar (PDA) and incubated at $20^{\circ} \mathrm{C}$ for 3 days. The growing fungi were isolated and purified on PDA and identified. The purified cultures were maintained on PDA and identified according to Raper and Thom (1968) in Mycological Lab.2 (ML2), Faculty of Science, Zagazig University. The media used for identification was Czapek's - agar medium.

\section{In vitro antifungal activity of chitosan}

The antifungal activity of chitosan against Botrytis cinerea was determined using PDA plates amended with $(1,2$ and $4 \%)$ chitosan. The PDA plates were prepared then inoculated with disks (3mm diameter) of fungal growth taken from 7 days old culture of Botrytis cinerea. The linear growth of the fungus was measured when control plates reached full growth.

\section{Preparation of inoculum}

Botrytis cinerea was isolated from infected Strawberries and maintained on Potato dextrose agar (PDA). Conidia of $B$. cinerea were recovered by filtering the mycelial suspension of 2 weeks old culture through 3 layers of sterile cheese cloth. The concentration of the conidial suspension was adjusted to $2 \times 10^{5}$ conidia per $\mathrm{mL}$.

After treatment, healthy and infected strawberries fruits with chitosan or with gamma irradiation were examined for diseases assessment (Severity \%) through different storage periods (weeks) under $13^{\circ} \mathrm{C}$.

Radiation: Strawberry fruits were exposed to different gamma irradiation doses 1.0, 1.5 and $2.5 \mathrm{KGy}$ in Indian $\mathrm{Co}^{60}$ gamma cell at the dose rate was $2.45 \mathrm{kGy} / \mathrm{hr}$ at the time of experiment. Each treatment was replicated three times, each replicate contains 15 fruit. All treated fruits and control were packed in perforated plastic containers and stored. The strawberry fruits were examined for disease assessment at different storage periods (1, 2 and 3 weeks).

Chitosan treatment: chitosan solutions were prepared by dissolving 1,2 and 4 gm of chitosan in 100 $\mathrm{mL}$ of distilled water with $2 \mathrm{~mL}$ acetic acid. Then heating with constantly agitation for $24 \mathrm{~h}$. The obtained solution was adjusted to $\mathrm{pH} 5.5$ by sodium hydroxide $0.1 \mathrm{~N}$; then $0.1 \mathrm{~mL}$ of tween 80 was added (H-Ghaouth et al., 1991). Sprayed fruits by the different coating chitosan concentrations were stored after treatment.

\section{Quality parameters:}

1- Total soluble solids (TSS): TSS content expressed in Brix was determined using ago (Japan) NI refractometer according to Kader (1991).

2- Firmness: Firmness (Firm) was measured as the maximum penetration force reached during tissue breaking of each fruit with hand penetrometer equipped with 1-9 $\mathrm{mm}$ diameter plunger $\left(\mathrm{g} / \mathrm{Cm}^{2}\right)$ according to Kader (1991).

3- Ascorbic acid (Vitamin C): Ascorbic acid content was determined by titration in the presence of 2.6 dichlorophenol- indophenol dye as an indicator against $2 \%$ oxalic acid solution as substrate. Ascorbic acid was calculated as milligram L-ascorbic acid per $100 \mathrm{~mL}$ of juice as described by Lucoss (1994).

\section{Determination of peroxidase activity:}

Samples of infected strawberry fruits treated with chitosan 4\%, gamma irradiation $2.5 \mathrm{kGy}$ and combination of chitosan $4 \%$ and $2.5 \mathrm{KGy}$, were collected after 10 days storage at $13^{\circ} \mathrm{C}$ for peroxidase activity assay. Also, infected fruits without treatment were used as control. Enzyme extract was obtained by grinding fruits tissues ( $2 \mathrm{ml} / \mathrm{g}$ fruits tissue) in $0.1 \mathrm{M}$ sodium phosphate buffer at $\mathrm{pH}(7.1)$ in a porcelain mortar and extracted. The extracted tissues were strained through four layers of cheesecloth. Filtrates were centrifuged at $3000 \mathrm{rpm}$ for 20 $\min$. at $6^{\circ} \mathrm{C}$. The clear supernatants were collected and considered as crude enzyme extract. Peroxidase activity was expressed as changes in absorbance/min at $425 \mathrm{~nm}$ according to the method of Allam and Hollis (1972). Determination of peroxidase enzyme was conducted in Central Lab. of Biotechnology, Plant Pathology Research Institute, Agricultural Research Centre, Egypt.

\section{Scanning electron microscopy:}

Mycelia of $B$. cinerea grown in PD broth medium treated with chitosan $4 \%$ and that from nontreated (control) were fixed in $2.5 \%$ glutaraldhyde at $4^{\circ} \mathrm{C}$ for $24 \mathrm{hr}$ and post-fixed in $1.0 \%$ osmium tetraoxide for one $\mathrm{hr}$ at room temperature (Harley and Fergusen, 1990). The specimens were then dehydrated with ascending concentrations of acetone, critical point dried, 
and finally sputter coated with gold. The examination and photographing were done through Joel Scanning Electron Microscope (JSM - 1200 EX).

Conclusion

This study demonstrated that chitosan plays an important role as an antifungal against Botrytis cinerea. Also, chitosan coating (4\%) significantly caused an increase in fruit firmness whereas TSS was decreased with an increase by increasing in storage time. However, Vitamin $\mathrm{C}$ gave fluctuated results by increasing storage time. Gamma irradiation at $2.5 \mathrm{KGy}$ reduced severity (\%), but combination of gamma irradiation with chitosan was more effective in altering fungus morphology and cell structure damage and no spore forming. This providing the efficiency of combination on reducing disease severity (\%) of strawberry.

\section{Disclosure statement}

No potential conflict of interest was reported by the authors.

\section{Funding}

There is no Fund, but this work was carried out in Food irradiation department, National Center for Radiation Research and Technology, Atomic Energy Authority and Mycological Res. and Plant Dis. Survey Dept., Plant Pathology Research Institute, Agricultural Research Center, Giza, Egypt

Experimental design and statistical analysis:
All treatments in this study were arranged in complete randomized design. The obtained data were subjected to analysis of variance using the general linear module procedure of SAS (1985), where appropriate treatment means were separated using Duncan's multiple range test (Duncan 1955) and all percentages were transferred to angles before statistical analysis.

\section{RESULTS}

Antifungal activity of different chitosan concentrations on Botrytis cinerea

The obtained data from Table (1) and show the correlation between increased chitosan concentrations with decreased the linear growth of Botrytis cinerea.

Table.1: Effect of different chitosan concentrations on radial growth of Botrytis cinerea

\begin{tabular}{|c|c|c|}
\hline $\begin{array}{l}\text { chitosan } \\
\text { concentrations \% }\end{array}$ & $\begin{array}{c}\text { Linear growth } \\
(\mathbf{c m})\end{array}$ & inhibition \% \\
\hline $\mathbf{0}$ & $\mathbf{9 . 0} \mathrm{A}$ & $\mathbf{0 . 0} \mathrm{D}$ \\
\hline 1 & $\mathbf{7 . 0} \mathrm{B}$ & $\mathbf{3 0 ~ C}$ \\
\hline 2 & $5.0 \mathrm{C}$ & $\mathbf{5 0 ~ B}$ \\
\hline 4 & $\mathbf{2 . 0} \mathrm{D}$ & $\mathbf{8 0} \mathrm{A}$ \\
\hline
\end{tabular}

* Means having the same letters in each column are statistically insignificant at $5 \%$ level.

Table.2: Effect of different gamma irradiation and Chitosan treatment on (severity \%) of strawberries fruits gray mold at different storage periods (weeks).

\begin{tabular}{|c|c|c|c|c|c|c|}
\hline \multirow{2}{*}{$\begin{array}{c}\text { Storage periods } \\
\text { (weeks) }\end{array}$} & \multirow{2}{*}{$\begin{array}{c}\text { Gamma doses } \\
\text { kGy }\end{array}$} & \multicolumn{2}{|c|}{ Severity \% } & \multirow{2}{*}{$\begin{array}{c}\text { Chitosan } \\
\%\end{array}$} & \multicolumn{2}{|c|}{ Severity \% } \\
\hline & & Infected & Non-infected & & Infected & Non-infected \\
\hline \multirow{4}{*}{1} & $\overline{0}$ & $55.5 \mathrm{~A}$ & $48.9 \mathrm{~A}$ & $\overline{0}$ & $59.8 \mathrm{~A}$ & $42.4 \mathrm{~A}$ \\
\hline & 1 & $45.3 \mathrm{~B}$ & $40.1 \mathrm{~B}$ & 1 & $31.1 \mathrm{~B}$ & $21.6 \mathrm{~B}$ \\
\hline & 1.5 & $38.4 \mathrm{C}$ & $29.8 \mathrm{C}$ & 2 & $20.1 C$ & $7.2 \mathrm{C}$ \\
\hline & 2.5 & 31.7D & 23.3D & 4 & 9.7D & $2.4 \mathrm{D}$ \\
\hline \multirow{4}{*}{2} & 0 & $100.0 \mathrm{~A}$ & $\overline{100.0 \mathrm{~A}}$ & 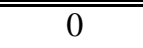 & $89.4 \mathrm{~A}$ & $\overline{c 77.66 \mathrm{~A}}$ \\
\hline & 1 & $73.8 \mathrm{~B}$ & $45.5 \mathrm{~B}$ & 1 & $57.3 \mathrm{~B}$ & $30.1 \mathrm{~B}$ \\
\hline & 1.5 & $65.6 \mathrm{C}$ & 41.7C & 2 & $39.9 \mathrm{C}$ & $20.4 \mathrm{C}$ \\
\hline & 2.5 & 45.9D & 25.1D & 4 & $33.8 \mathrm{D}$ & 16.9D \\
\hline \multirow{4}{*}{3} & $\overline{0}$ & $100.0 \mathrm{~A}$ & $100.0 \mathrm{~A}$ & $\overline{0}$ & $100.0 \mathrm{~A}$ & $100.0 \mathrm{~A}$ \\
\hline & 1 & $80.8 \mathrm{~B}$ & $54.4 \mathrm{~B}$ & 1 & $62.5 \mathrm{~B}$ & 40.4B \\
\hline & 1.5 & $69.7 \mathrm{C}$ & $46.3 \mathrm{C}$ & 2 & $53.4 \mathrm{C}$ & $28.1 \mathrm{C}$ \\
\hline & 2.5 & 49.9D & 29.1D & 4 & $40.1 \mathrm{D}$ & $19.2 \mathrm{D}$ \\
\hline
\end{tabular}

* Means having the same letters in each column are statistically insignificant at $5 \%$ level.

Data in Table (2) show the effect of different gamma irradiation doses (1, 1.5 and $2.5 \mathrm{KGy})$ and different chitosan concentrations $(0,1,2$ and $4 \%)$ coating on severity $(\%)$ of strawberry fruits at $13^{\circ} \mathrm{C}$ for different periods $(1,2,3$ weeks $)$.

The obtained data show that as chitosan $\%$ increased the severity $\%$ decreased. The lowest severity $\%$ 
obtained at $4 \%$ chitosan. Also, as the storage period increases the severity $\%$ increases. Moreover, as storage period increases the severity $(\%)$ increases, and different doses of gamma ray decreased the severity (\%).2.5 KGy was the effective dose that decreased severity $(\%)$ in different storage periods.

Effect of chitosan concentrations, storage time and Botrytis cinerea infection on some strawberries quality parameters.
Data in Table (3) show that interaction between storage time and chitosan treatments on quality parameters of strawberry fruits, Data indicate that, treating strawberries with chitosan significantly decreased the values of TSS by increasing storage time (1, 2, 3 weeks) while an opposite effect was obtained in firmness, which increased by using chitosan coating at different concentrations $(0,1,2$ and $4 \%)$, since at $4 \%$ chitos an give the highest values of TSS, firmness and vitamin $\mathrm{C}$ at different storage periods.

Table.3: Effect of chitosan treatment concentrations, storage time (weeks) and Botrytis cinerea infection on some strawberries quality parameters at $13^{\circ} \mathrm{C}$.

\begin{tabular}{|c|c|c|c|c|c|c|c|}
\hline \multirow{2}{*}{$\begin{array}{c}\text { Storage } \\
\text { period } \\
\text { (week) }\end{array}$} & \multirow{2}{*}{$\begin{array}{c}\text { Chitosan } \\
\%\end{array}$} & \multicolumn{2}{|c|}{ TSS (Brix) } & \multicolumn{2}{|c|}{ Firmness $\left(\mathrm{g} / \mathrm{Cm}^{2}\right)$} & \multicolumn{2}{|c|}{ Vitamin C (mg) } \\
\hline & & Infected & $\begin{array}{c}\text { Non- } \\
\text { infected }\end{array}$ & Infected & $\begin{array}{c}\text { Non- } \\
\text { infected }\end{array}$ & Infected & $\begin{array}{c}\text { Non- } \\
\text { infected }\end{array}$ \\
\hline \multirow{4}{*}{1} & 0 & $5.90 \mathrm{D}$ & $6.73 \mathrm{D}$ & $400.0 \mathrm{~B}$ & $422,5 \mathrm{C}$ & $0.024 \mathrm{D}$ & $0.028 \mathrm{C}$ \\
\hline & 1 & $6.88 \mathrm{C}$ & $6.87 \mathrm{C}$ & 404.1B & $423.3 \mathrm{C}$ & $0.025 \mathrm{C}$ & $0.029 \mathrm{~B}$ \\
\hline & 2 & $7.01 \mathrm{~B}$ & $7.10 \mathrm{~B}$ & 453.7A & 448.7B & $0.027 \mathrm{~B}$ & $0.029 \mathrm{~B}$ \\
\hline & 4 & $7.21 \mathrm{~A}$ & $8.21 \mathrm{~A}$ & $457.6 \mathrm{~A}$ & $450.1 \mathrm{~A}$ & $0.030 \mathrm{~A}$ & $0.031 \mathrm{~A}$ \\
\hline \multirow{4}{*}{2} & 0 & $5.35 \mathrm{D}$ & $5.91 \mathrm{C}$ & $299.1 C$ & 342.7D & $0.021 \mathrm{C}$ & $0.019 \mathrm{C}$ \\
\hline & 1 & $5.68 \mathrm{C}$ & $6.12 \mathrm{~A}$ & $301.8 \mathrm{C}$ & $345.8 \mathrm{C}$ & $0.022 \mathrm{C}$ & $0.019 \mathrm{C}$ \\
\hline & 2 & $5.79 \mathrm{~B}$ & $6.33 \mathrm{~B}$ & $330.9 \mathrm{~B}$ & $352.1 \mathrm{~B}$ & $0.025 \mathrm{~B}$ & $0.020 \mathrm{~B}$ \\
\hline & 4 & $6.13 \mathrm{~A}$ & $7.10 \mathrm{~A}$ & $345.5 \mathrm{~A}$ & $359.3 \mathrm{~A}$ & $0.030 \mathrm{~A}$ & $0.027 \mathrm{~A}$ \\
\hline \multirow{4}{*}{3} & 0 & $5.09 \mathrm{D}$ & 4.13D & 198.01D & $225.8 \mathrm{~A}$ & $0.015 \mathrm{D}$ & $0.019 \mathrm{C}$ \\
\hline & 1 & $5.40 \mathrm{C}$ & $5.01 \mathrm{C}$ & $200.0 \mathrm{C}$ & 235.3B & $0.018 \mathrm{C}$ & 0.019C \\
\hline & 2 & $5.70 \mathrm{~B}$ & $5.93 B$ & 214.8B & $240.2 \mathrm{C}$ & $0.023 \mathrm{~B}$ & $0.020 \mathrm{~B}$ \\
\hline & 4 & $6.01 \mathrm{~A}$ & $6.01 \mathrm{~A}$ & $220.6 \mathrm{~A}$ & $245.7 \mathrm{C}$ & $0.025 \mathrm{~A}$ & $0.023 \mathrm{~A}$ \\
\hline
\end{tabular}

* Means having the same letters in each column are statistically insignificant at 5\% level

Combination of gamma irradiation and chitosan on strawberry fruits gray mold at different storage periods (weeks) at $13^{\circ} \mathrm{C}$.

Data in Table (4) show that combination effect of gamma ray $(2.5 \mathrm{KGy})$ and chitosan $(4 \%)$ on severity $(\%)$ of gray mold on strawberry fruits. The combination between gamma ray (2.5 KGy) and chitosan (4\%) was more effective to reduce severity $(\%)$ as compared when we used chitos an (4\%) alone or when used gamma rays at (2.5 KGy) alone, since combination reduced severity (\%) from 55.5, 48.9 to $8.5,2.1$ for infected and healthy fruits respectively at first week, from 100.0, 100.0 to $19.9,8.7$ for infected and healthy fruits respectively at second week and at third week severity (\%) of infected and healthy fruits decreased from 100.0, 100.0 to 24.7, 18.9, respectively. 
Table.4: Combination of gamma irradiation and chitosan on strawberry fruits gray mold (severity \%) at different storage periods (weeks).

\begin{tabular}{|c|c|c|c|}
\hline \multirow{2}{*}{$\begin{array}{l}\text { Storage period } \\
\text { (week) }\end{array}$} & \multirow[t]{2}{*}{ Treatment } & \multicolumn{2}{|c|}{ Severity \% } \\
\hline & & Infected & Non-infected \\
\hline 1 & $\begin{array}{l}\text { Control } \\
\text { Chitosan }(4 \%) \\
2.5 \mathrm{KGy} \\
2.5 \mathrm{KGy}+\text { Chitosan }(4 \%)\end{array}$ & $\begin{array}{c}55.5 \mathrm{~A} \\
10.8 \mathrm{C} \\
31.7 \mathrm{~B} \\
8.5 \mathrm{D}\end{array}$ & $\begin{array}{c}48.9 \mathrm{~A} \\
4.5 \mathrm{C} \\
26.3 \mathrm{~B} \\
2.1 \mathrm{D}\end{array}$ \\
\hline 2 & $\begin{array}{l}\text { Control } \\
\text { Chitosan }(4 \%) \\
2.5 \mathrm{KGy} \\
2.5 \mathrm{KGy}+\text { Chitosan }(4 \%)\end{array}$ & $\begin{array}{c}100.0 \mathrm{~A} \\
33.8 \mathrm{C} \\
48.9 \mathrm{~B} \\
19.9 \mathrm{D}\end{array}$ & $\begin{array}{c}100.0 \mathrm{~A} \\
16.9 \mathrm{C} \\
25.1 \mathrm{~B} \\
8.7 \mathrm{D}\end{array}$ \\
\hline 3 & $\begin{array}{l}\text { Control } \\
\text { Chitosan }(4 \%) \\
2.5 \mathrm{KGy} \\
2.5 \mathrm{KGy}+\text { Chitosan }(4 \%)\end{array}$ & $\begin{array}{c}100.0 \mathrm{~A} \\
40.1 \mathrm{C} \\
49.9 \mathrm{~B} \\
24.7 \mathrm{D}\end{array}$ & $\begin{array}{c}100.0 \mathrm{~A} \\
19.2 \mathrm{C} \\
29.1 \mathrm{~B} \\
18.9 \mathrm{C}\end{array}$ \\
\hline
\end{tabular}

* Means having the same letters in each column are statistically insignificant at 5\% level.

Effect of gamma irradiation $(2.5 \mathrm{kGy})$, chitosan $(4 \%)$ and their combination on peroxidase activity in strawberry fruits infected with $B$. cinerea and stored for one week

Results in Fig (1) Show that strawberry fruits inoculated with $B$. cinerea treated with combination of chitosan (4\%) and gamma irradiation $2.5 \mathrm{kGy}$ induce higher activity of peroxidase (POD) enzyme. followed by chitosan (4\%) and gamma irradiation $2.5 \mathrm{kGy}$ irrespectively as compared with control fruits after oneweek storage periods. 


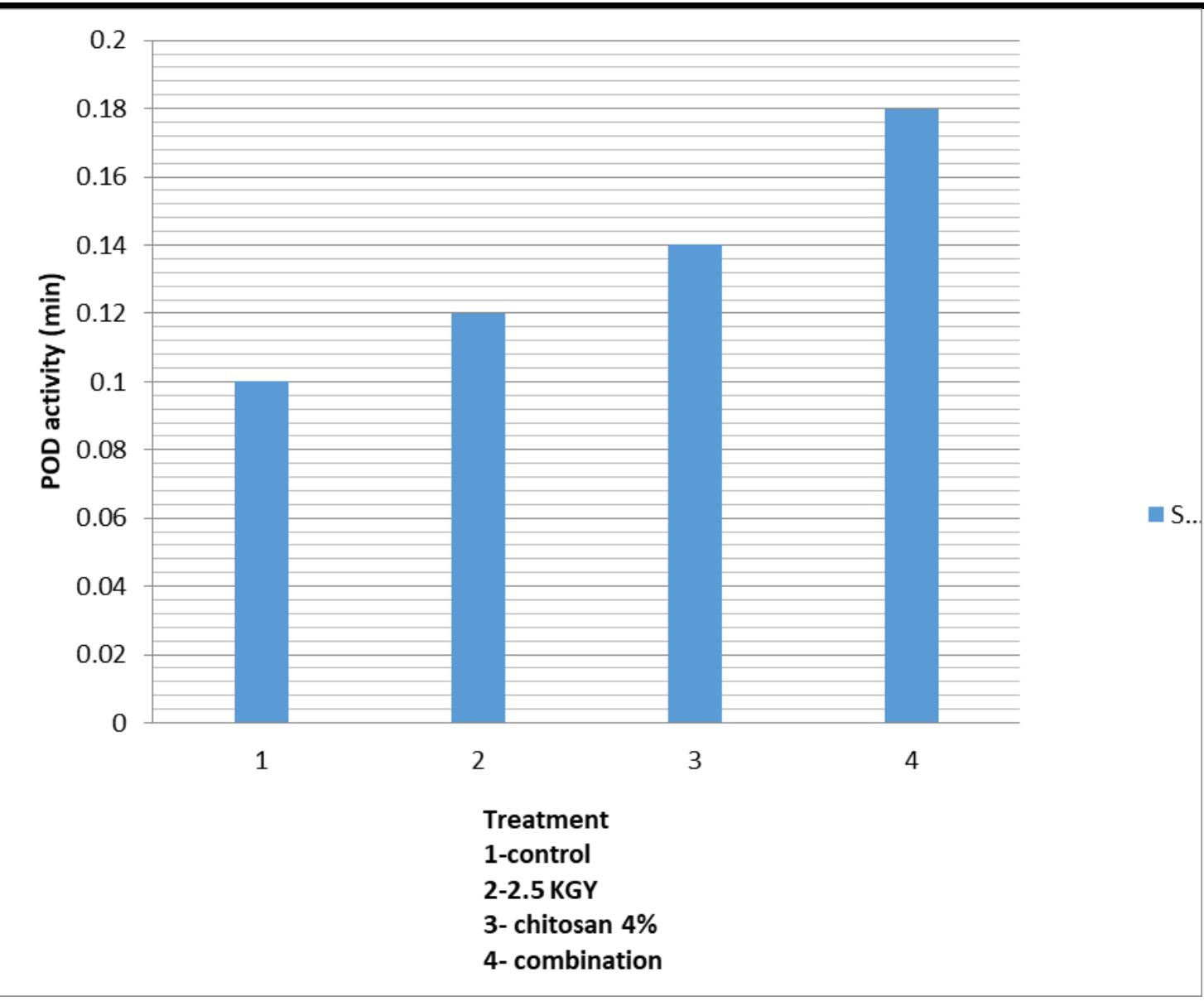

Fig.1: Effect of gamma irradiation (2.5 kGy), chitosan (4\%) and combination between gamma irradiation and chitosan on peroxidase enzyme activity in strawberry fruits infected with B. cinerea and stored for one week

\section{Scanning electron microscopy}

Fig. (2) showed the morphological changes occurred in hyphae and conidiophores of $B$. cinerea treated with chitosan (4\%), gamma irradiation $2.5 \mathrm{kGy}$ and combination between chitosan (4\%) and gamma irradiation $2.5 \mathrm{kGy}$ irrespectively

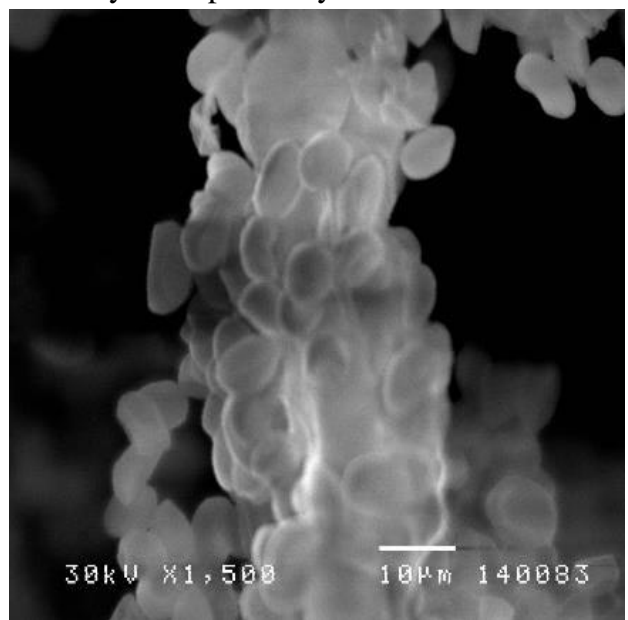

Fig.2A) Control

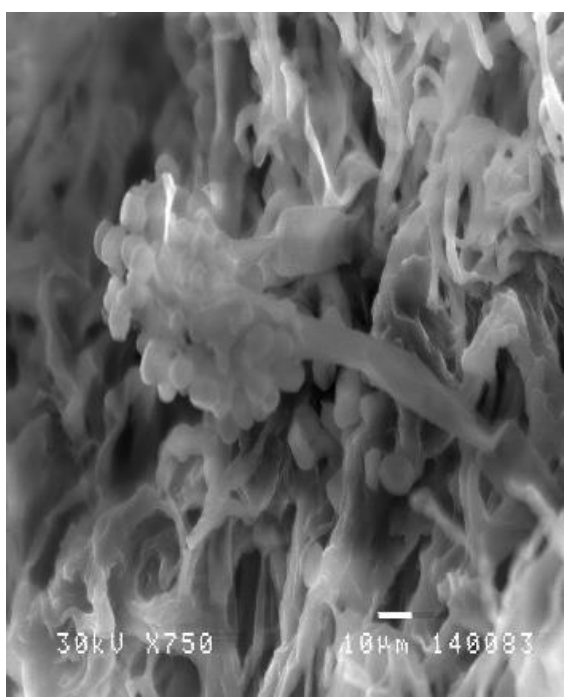

Fig.2B) Chitosan treatment 


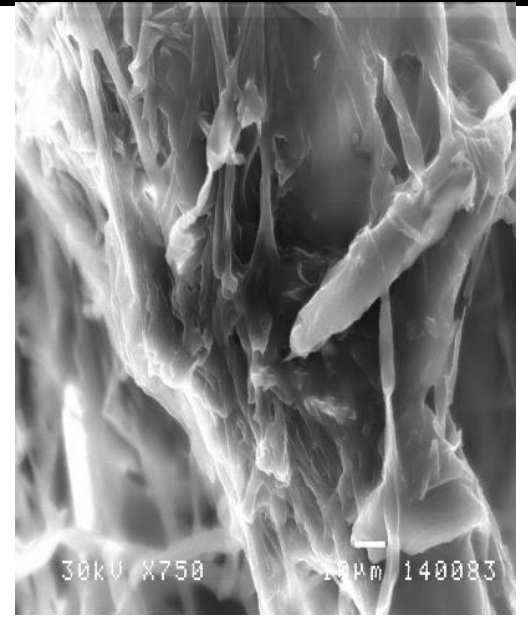

Fig. (2C) Gamma irradiation treatment

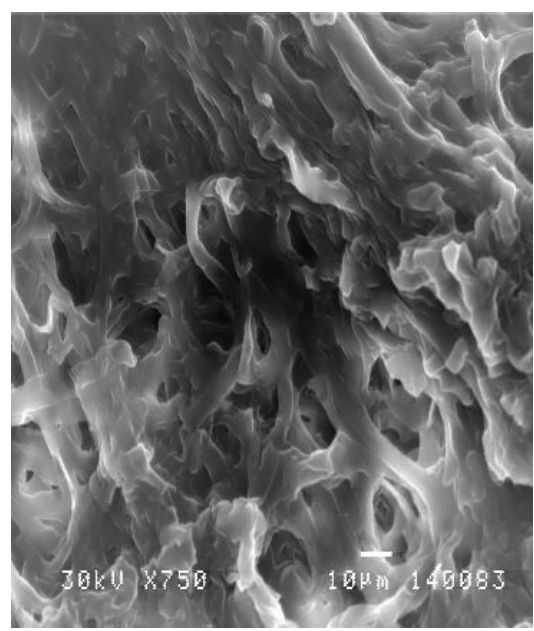

Fig. (2D) combination treatment

Fig.2 Scanning electron microscopy examinations of B. cinerea as affected by chitosan and gamma irradiation

It was found that control fungus $B$. cinerea have normal hyphea, sporangium, sporangiophore and normal cell wall and spore (Fig. 2A).

Chitosan treatment $(4 \%)$ induced changes in surface morphology and cause damage to cell structure of B.cinerea and sporangiophore without spore(Fig. 2B).

Gamma irradiation induced changes in surface morphology and cause damage to hypha also an affected sporangiophore (Fig. 2C).

The combination effect of chitosan (4\%) and gamma irradiation $2.5 \mathrm{kGy}$ on $B$. cinerea show more destructive effect in surface morphology and more effective damage to cell structure, corrugate surface and no spore found (Fig. 2D).

\section{DISCUSSION}

Several studies have been performed to extend strawberry fruits shelf-life, using alternative methods rather than chemicals to avoid residues such as fungicide residues for the fruit itself (Peng and Sutton, 1991) and to avoid pathogen populations from developing resistance to pesticides (Bakkali et al., 2008).

Chitosan, a high molecular weight cationic polysaccharide, has been shown to be fungicidal against several fungi (E-Ghouth et al., 1990).

Chitosan $(4 \%)$ reduced the severity $\%$ of gray mold on different storage period and these results are in agreement with $\mathbf{L i}$ and $\mathbf{Y u}$ (2000), who confirmed the potential effect of chitosan to protect postharvest brown rot of peach caused by $M$. fructicola by decreasing the incidence, prolonging the incubation period, and reducing of brown rot was correlated with chitosan induction of defence response, in addition to its antifungal property. Romanazzi et al. (2000) reported that strawberries dipped in $1 \%$ and $0.5 \%$ chitos an decreased the gray mold infection from natural inoculum after 10-days of storage at $0 \mathrm{C}^{\circ}$. Followed by 4 days shelf-life. Casariego (2004) confirmed that chitosan films were also reported to inhibit the growth of fungi and yeasts in the area of contact, forming a halo of inhibition on the inoculated plates.

Atia et al. (2005) suggested that the mechanism by which chitos an coating reduced that decay of strawberries appear to be related to its fungistatic property rather than to its ability to induce defense enzymes such as chitinase, chitosanase and $\beta$-1,3-glucanase and its capacity to stimulate plant defense mechanisms (Aziz et al., 2006)

Ribeiro et al. (2007) explained that strawberry is non-climacteric fruits, but has a high postharvest respiration rate, which leads to a rapid deterioration at room temperature, coating with $1 \%$ chitosan reduced the growth rate of microorganisms in strawberries.

Romanazzi (2010) confirmed that pre-harvest and postharvest treatments by chitosan of table grapes, strawberries and sweet cherries reduce their decay under field and during storage.

Besides its antifungal activity, chitosan also has the potential role in inducing defense related enzymes (Bautista-Bonas et al., 2006) and phenolics in plants (Benhamou, 1996).

Ben-Shalom et al. (2003) demonstrated that POD activity was elicited by chitosan in cucumber, resulting in an increase in resistance against B. cinerea. Liu et al. (2007) confirmed that chitosan inhibits the growth of $B$. cinerea and $P$. expasumin vitro and potently induces defense reactions in tomato fruits.

Li et al. (2000) used chitosan as a semi-permeable coating and found that it can maintain the qualities of the treated fruit and prolong its storage life, chitosan slows down the deterioration of peaches by decreasing respiration rate and ethylene production, reducing malondialdehyde production, stimulation superoxide dismutase activity and maintaining membrane integrity. 
Chitosan has a double mechanism of action: it reduces the growth of decay causing fungi, and induces resistance responses in host tissues. With this double effectiveness chitosan can be considered as the first compound of a new class of plant protection products (Atia et al., 2005).

Hernandez-Lauzardo et al. (2011) demonstrate the mode of action of chitosan on different fungal pathogen. They reported that molecules of chitosan can penetrate the intracellular level and interact with intracellular structure and cause damage.

Greater effects of chitosan to inhabit the growth of B. cinarea and cause serious damage to fungal cell structure as well as the ability to form an impervious layer around the cell, therefore, chitosan could be considered as a potential alternative for synthetic fungicides (Silva Junior et al., 2014).

SEM shows that chitosan caused changes in the morphology of $B$. cinerea and caused damage to cell structure also gamma irradiation cause changes in surface morphology and caused damage to hypha. As well as, sporangiophore. The combination between chitosan (4\%) and gamma irradiation (2.5 kGy) shows more destructive effect in surface morphology and more damage to cell structure. These results are in agreement with Swelim (2004) who confirmed that scanning electron microscope showed that the decrease in sporulation and morphology abnormalities of Fusarium solani were occurred after irradiation with 6,8 and $10 \mathrm{kGy}$. Meanwhile, low dose levels (1, 2 and $3 \mathrm{kGy}$ ) caused malformation and compactness of mycelia as well as absence of sporulation in $F$. verticillioides.

Our results indicated that treating strawberries with chitosan significantly decreased the value of TSS by increasing storage time, while an opposite effect was obtained in firmness, which increased by chitosan coating. Vitamin C would not be detected in clear level of amounts. These results are in agreement with E-Gaouth (1991) and Luna et al. (2001) who reported that greater firmness of fruits such as strawberries, tomatoes and peaches were obtained when fruits coated with a chitosan. Also, Dam and Nguyen (2011) suggested that, all chitos an treatments enhanced the firmness of strawberries fruits compared to untreated fruits.

Gamma irradiation doses reduced the severity (\%) of strawberry fruits in our obtained results and $2.5 \mathrm{kGy}$ doses was the most effective in decreasing the disease severity, these obtained results are in agreement with Shadia and Ehab (2011), who confirmed that gamma radiation decreased the percentage of infection of strawberry fruits artificially inoculated with $B$. cinerea and naturally infected at $2.5 \mathrm{KGy}$ compare with control.
The results recommended using combination of chitosan and gamma radiation in order to reduce the disease development and extend the shelf-life of strawberry.

\section{REFERENCES}

[1] Allam, A. I. and Hollis, S. P. (1972): Sulfide inhibition of oxidase in rice root phytopathology, 62: 634-639.

[2] Ana Niurka Hernandez-Lauzardo, Miguel Gerardo Velazquez-del Valle and Maria Guad GuerraSanchez, (2011): Current status of action mode and effect of chitosan against phytopathogenis fungi. African J. Microbiol. Res., 2: 4243-4247.

[3] Atia, M. M. M.; Buchenauer, H., Aly, A. Z. and Abou-Zaid, M. I. (2005): Antifungal activity of chitos an against Phytophthora infestans and activation of defence mechanisms in tomato late blight. Polym. Buul., 20: 83-88.

[4] Aziz, A., Trotel-Aziz, P., Dhuicq, L., Jeander, P., Coudercher, M., Vernet, G., (2006): Chitosan Oligomers and copper sulfate induce grapevine mildew. Phytopathology, 96: 1188-1194.

[5] Bakkali, F.; Averbeck, S.; Averbeck, D. and Idaomar, M. (2008): Biological effects of essential oils. A review: Food and Chem. Toxicol., 46: 446-475.

[6] Bautista-Banos, S., Hernandez-Lauzardo, A. N., Velazquez-del Valle, M.G., Hernandez- Lopez, M., AitBarka, E. Bosquez-Molina, E, Wilson, C.L., (2006): Chitosan as a potential natural compound to control pre and postharvest disease of horticultural commodities. Crop. Prot., 25, 108-118.

[7] Benhamou, N., (1996): Elicitor-induced plant defense pathways. Trends Plant Sci., 1: 233-240.

[8] Ben-Shalom, N., Ardi, R., Pinto, R., Aki, C., Fallik, E, (2003): Controlling gray mould caused by Botrytis cinerea in Cucumber plants by means of chitosan. Crop. Prot., 22: 285-290.

[9] Braun, P. G. and Sutton, J. C., (1987): Inoculum sources of Botrytis cinerea in Fruit rot strawberries in Ontario. Can. J. Plant Pathol., 9: 1-5.

[10] Casariego, A. (2004): Obtencion de pellicles antimicrobian as a partir de quitosana. Cienciay Tecnologia de los Alimentos, 14: 11-14.

[11] Dam, S. M. and Nguyen, H. X. P. (2011): The effect of the neem seed extract (Azadirachtin indica), Chitos an and $\mathrm{CaCl}_{2}$ on strawberry (Fragaria ananassa) storage. The $12^{\text {th }}$ Asian Food Conference, Thailand.

[12] Duncan, D. B. (1955): Multiple range and multiple F. tests. Biometrics, 11: 1-42.

[13] E-Ghaouth, A.; Arul, J. and Ponnampalam, R., (1990): The effect of chitosan on growth and morphology of Rhizopus stolonifer. (Abst.). Phytopathology, 80: 1020.

[14] Eun- Hee Chu, Eun-Jung Shin and Hae-Jun Park (2015): Effect of gamma irradiation and its convergent 
treatment for control of pos tharvest Botrytis cinerea of cut roses. Radiation physics and chemistry, 115: 22-29.

[15] Harley, M.M. and Fergusen, I.K. 1990: The role of SEM in pollen morphology and plant systematic. Association special, 41: 45-68, Clarendon press, oxford.

[16] Hongye Li and Ting Yu (2000): Effect of chitos an on incidence of brown rot, quality and physiological attributes of postharvest peach fruit. Journal of the Science of Food and Agriculture, 81(2): 269-274.

[17] Hongye Li and Ting Yu, (2001): Effect of chitosan on incidence of brown rot, quality and physiological attributes of postharvest Peach fruit. Journal of the Science of food and Agriculture, 18 (2): 269-274.

[18] Hussain, P. R., Dar, R. S. and Wani, A. M. (2013): Impact of radiation processing on quality during storage and post-refrigeration decay of plum (Prunus domestica L.) cv. Santaroza. Rad. Phys. and Chem.. 4(1): 1016-1020.

[19] Jia Liu, Shiping Tian, Xianghong Meng and Yong X.U., (2007): Effects of chitosan on control of postharvest diseases and physiological responses of tomato fruits. Postharvest biology and Technology 44: 300-306.

[20] Kader, A. A. (1991): Quality and its maintenance in relation to the posthavest physiology of strawberry. The strawberry into the $21^{\text {st }}$. century: Proc, third North Amer. Strawberry Conf. Timber press, Portland. OR, PP. 145-152.

[21] Lucoss, E. H. (1994): Determination ascorbic acid in large numbers of plant samples. Ind. Eng. Chem. Anal., 15: 649-652.

[22] Luna, D.; Bustamanta, L. M.; Gonzalez, G.; Dominguez, S. J.; Bautista, B. S.; Shirai, K. and Bosquez, M. E (2011): Treatments on the quality of papaya fruit during storage. Proceeding of the Eighth international congress on Engineering Food. Technomic publishing Co. Inc., Lancaster, Abstr., PP.: 1042-1046.

[23] Milena petriccione, Francesco Mastrobuoni, Maria Silvia pasquariello, Luigi Zampella, Elvira nobis, Giuseppe Capriolo and Marco Scortichini (2015); Effect of chitosan coating on postharvest quality and antioxidant enzyme systemres ponse of strawberry fruit during cold storage. Foods ISSN 2304-8158, 4: 501523.

[24] Peng, G. and Sutton, J. C. (1991): Evaluation of microorganism for biocontrol of Botrytis cinerea in strawberry. Can. J. plant pathol., 13: 247-257.

[25] Raper, K. B. and Thom, C. (1968): A manual of the penicillia. Hafner publishing company, New York and London.

[26] Rayees Ahmed Shiekh, Maqsood Ahmed Malik, Shaeel Ahmed Al-ThaBatti and Muneer Ahmed Shiekh (2013); Chitosan as a Novel Edible coating for fresh fruits. Review. Food Sci. Technol. Res., 19(2): 139-155.

[27] Ribeiro, C.; Vicenta, A. A.; Teixeira, J. A. and Miranda, C. (2007): Optimization of edible coating composition to treat strawberry fruit senesce. Postharvest Biol. and Tech., 44: 63-70.

[28] Romanazzi, F; Nigro, F. and Ippolito, A. (2000): effect to di trattamenti pre postraccolta con chitosan sui marciumidellafragola in conservazionre. Rivista di Frutticoltura, 62(5): 71-75.

[29] Romanazzi, G. (2010): Chitosan treatment for the control of postharvest decay of table grapes, strawberries and sweet cherries. Fresh Produce 4 (Special Is sue), 111-115.

[30] Romanazzi, G., Feliziani, E, Santini, M. and Landi, L. (2013): Effectivenes s of postharvest treatment with chitos an and other resistance inducers in the control of storage decay of strawberry. Postharvest biology and technology, volume 75. January, pages 24-27.

[31] SAS "Statistical Analysis System" (1985): SAS/STAT user's guide: statistics, vesion 6. 0.3 Edition. SAS Institute Ic. Cary, N. C. USA.

[32] Shadi, A. A. and Ehab, A. S. (2011): Effect of some Antioxidants, caraway oil (Carium carvum L.) and Gamma Radiation on Gray Mold of strawberry fruits during storage. J. Rad. Res. Appl. Sci., vol., 4(B): 1415-1428.

[33] Silva Junior S., Stamford N., P., Lima M.A.B., Arnaud, T.M.S., Pintado, M.M. and Sarmento, B. F., (2004): Characterization and inhibitory activity of chitos an on hyphagrowth and morphology of Botrytis cinerea plant pathogen. International Journal of Applied Research in Natural Products, 7(4): 31-38.

[34] Swelim, M.A., (2004): Effect of gamma irradiation on growth and cellular structure of two Fusarium species. Is otope and Rad. Res., 36, 135-150.

[35] Tarek, S.S.S. (2004): Integrated control for minimizing postharvest diseases of strawberry. M.Sc. thes is, Fac. Agric. Ain shams Univ., 165pp.

[36] Vargas, M.; Albors, A.; Chiralt, C. and Gonzalez Martinez, S. (2006): Quality of cold-stored strawberries as effected by chitos an-oleic acid edible Coatings. Postharvest Biol. and Tech., 41: 164-171. 